\title{
'My husband is interested in war generally': Gender, family history and the emotional legacies of total war
}

Lucy Noakes: University of Brighton

\section{Introduction}

In the autumn of 2014, as Britain embarked on four years of commemorative activities to mark the centenary of the First World War, the Mass Observation (MO) Project issued a Directive to its respondents, asking them to reflect on their feelings about the war. The Directive was commissioned by the five AHRC World War One Engagement Centres as a means of both capturing the responses of the British people to the centenary, and to provide a snapshot of the cultural memory of the war that was circulating in Britain in late $2014 .{ }^{1}$ Among the questions asked were 'do stories about the First World War feature in your family?' 'Have you read any books, or watched any television programmes or films about the war?' and 'Do you observe Remembrance Day?' In addition, respondents were asked to keep a day diary for either Remembrance Sunday, which fell on the 9th November, or Armistice Day itself, 11th November 2014.

This article examines some of these responses, considering the ways in which these were shaped by gender and by generational position. It focuses upon the responses of women born between the 1920s and the early 1950s. While these women do not constitute a single generation, being aged between 93 and 60 at the time of writing, with the majority of those whose responses were analysed being in their 70s and $80 \mathrm{~s}$, they can be understood as, in Marianne Hirsch's words, 'the generation after'. By this, Hirsch is referring to a group whose 
relationship to a past event (in Hirsch's example the Holocaust, here the First World War) is shaped by the impact of this event on those who had first hand experience, which they then “remember'... by means of the stories, images and behaviours by which they grew up. ${ }^{2}$ For Hirsch, this 'postmemory' is differentiated from the memories of those with experience of the same past events by its 'imaginative investment', but it shares with them an emotional power, and acts as a means by which emotional connections are made across generations. ${ }^{3}$ While none of these women was old enough to have had personal experience of the war years, they were all of an age to have known veterans, to have heard some of their stories, and at times to have had their own early lives shaped by the impact of the war, and the stories that circulated about it. Their experiences also differed widely of course. As well as the usual differences of class, of occupation, family position and other determining factors, they were divided by history, with the older respondents having experienced the Second World War as adults, while the younger were born in the decade after its end. They were all, however, old enough to have close family members, parents, grandparents, aunts and uncles, who had first hand experience of the First World War and to themselves have formed an impression of the war years which preceded the current cultural memory of the war, which began to emerge in the 1960s and which has been described by Helen McCartney as 'a byword for futility'. 4 They were also all women, a group whose wartime experiences, as this article will go on to demonstrate, have been largely marginal to the wider cultural memory of the war in circulation.

As Hirsch notes, family history, with its ability to reduce distance and abstraction, and its emotional resonance for many, can provide a powerful means for people to engage with the events of the past. ${ }^{5}$ Indeed, as much recent work with community groups on the centenary of 
the First World War has demonstrated, family history has emerged as one of the key ways in which individuals are connecting to commemorative activities. ${ }^{6}$ This article examines the interaction between these family histories and the wider, public, memories of the war that have circulated since its conclusion. It considers how these forces may have formed these women's relationships to the war, examining both the appearance of popular narratives of the war in the Directive replies, and the ways in which these were shaped by family history and family and generational position. Firstly though, it considers the ways in which war memories can be understood as gendered.

\section{Gendering war memories}

The transmission of war memories across generations is a subject that has recently been of interest to a number of scholars. ${ }^{7}$ Michael Roper's work on the emotional impact and life long legacies of the First World War on the men who fought in this conflict and their families considers the idea of a male 'war generation' whose emotional, familial and psychic lives were shaped by this defining experience. He has examined this firstly through a careful study of the letters which passed between home front and war front, and later autobiographical retellings of war experiences, and secondly, through a focus on the stories that veterans' children tell. In both studies, the idea that the war has an afterlife, that it lives on through memory, through culture, through its familial, physical, emotional and economic legacies, is central. ${ }^{8}$ In his oral history of the ways that the memory of the First World War influenced male attitudes to military service in the Second World War, Joel Morley considers the ways that young men encountered ideas about what warfare and military service entailed through conversations with older men in their families. In the passing on of versions of their 
experiences through family stories and conversations, First World War veterans contributed to the 'scripts' from which younger men built their own identities and understood both models of masculinity that were circulating and their own place in their families. ${ }^{9}$ These studies illustrate some of the ways that war stories entered into family life, and demonstrate that, counter to the cultural archetypes of the expressive war poet and the silent, traumatised veteran, unable to speak of his experiences and thus unable to heal himself, the majority of men sat somewhere in between; attempting to compose stories about the war that they were comfortable with, and which transmitted particular narratives of service and models of masculine behaviour to the younger men in their families, while perhaps remaining silent about other experiences, and amongst other audiences.

However, while these studies explore the ways in which memories and narratives of war are transmitted across generations, they both focus on the ways that these are transmitted by male veterans, and consider subsequent generations through their relationship to these men, to their experiences and memories. The privileging of the narrative of this male veteran over other types of war experience, and other forms of identity that can be seen here is a part of wider patterns in Britain of the cultural memory of the war years. To some extent, academic histories of the war and its multiple legacies are marginal to a widely shared historical understanding of the conflict, which continues to largely focus on the male experience of the Western Front. While there is a large body of research on the gendered history and experience of the First World War, the impact of this work on cultural memory of the conflict has been marginal. ${ }^{10}$ While the experiences of the 'home front' in general have been examined in several recent fictionalised representations of the war, the experience of the man on the Western Front has maintained its centrality. Thus, even in the television costume 
dramas of the early $21^{\text {st }}$ century, which have traditionally been understood as having a largely female audience, storylines driven by the events of the First World War, exploring their impact on and legacies for, those far away from the front line, the experience of the combatant remains fundamental. ${ }^{11}$ As the historian Bart Ziino has argued, 'we remain obsessed with 'the soldier's story." 12 Indeed, representations of women's multiple experiences of the war years, and the wide ranging and diverse legacies of the war in their lives remain marginal to British cultural memory of the First World War more broadly, the memoirs of Vera Brittain apparently functioning as a satisfactory representation of all female experience. ${ }^{13}$ While Penny Summerfield has written perceptively on gendered memories of the Second World War, there has been little consideration of the multiple ways that First World War stories might have shaped the scripts that were available to the daughters and granddaughters of the women who worked in the fields and factories, served in the militaries, nursed the combatants, bought up children, campaigned for peace, or contributed to or worked against total war in numerous ways between 1914 and $1918 .^{14}$

This focus on male stories of war, and their impact on the ideas of masculinity that were available to a younger generation of men is particularly interesting as women are often the key transmitters of stories within families and across generations. ${ }^{15}$ Many of the continuities of family life that our ancestors took for granted have been dissolved by the pressures and possibilities of modernity: families are less likely to share a home across multiple generations and may be spread across the globe. These changes, and the disruption that they can bring not only to family relations but to a stable sense of self, rooted in part in a secure relationship to the past, can help to explain the current popularity of genealogy as a leisure pursuit. Pierre Nora, writing about the history of France, and the ways in which this history fed into and 
shaped French national identity, identified moments of rupture and rapid social change as points at which history becomes particularly important and visible. As societies change, Nora argued, we become more and more attached to a 'memory' of the past, a memory which gives us a sense of stability and continuity. ${ }^{16}$ This desire for a knowable past operates on an individual and familial level, as well as the national level Nora identified. The multiple and rapid changes of recent years can help to account for the current popularity of family history as seen in the media, in local education classes and in the use of online commercial family history databases such as Ancestry.com. ${ }^{17}$ As Anne-Marie Kramer has argued 'this seemingly unprecedented boom in the family heritage industry' acts not only to build links between the past and the present, but enables individuals to construct subjectivities that position them in relation to this past. $^{18}$

Despite the popularity of family history as a leisure pursuit, as a means of identity formation and as a bounded means of carrying out historical research, academic history has often failed to pay serious attention to this form of historical research and writing. ${ }^{19}$ Family history operates in the public sphere as well as the more private and familial; for example the online projects Lives of the Great War and the BBC's The People's War both bring together multiple narrative accounts of the First and Second World Wars, often entered onto the websites by the children and grandchildren of veterans, keen to ensure that their familial experience has a place in wider histories of both conflicts. ${ }^{20}$ Indeed, the publication of family histories, and of the diaries, letters and autobiographies left by those who experienced both wars, has become a widespread phenomenon in Europe, Australia and the United States. ${ }^{21}$ As James Wallis has demonstrated, this family history, which he terms 'grass roots commemorative practice', is impacting on the wider cultural memory of both wars. ${ }^{22}$ 
Memories circulate and are reproduced and reformed within family and kinship networks, entering onto the public stage when they relate to elements of the wider cultural memory in circulation there. These more public representations of the past, which in the case of the First World War largely group around the tragic figure of the male combatant, and the legacy of his experiences for those at home, in turn shape the kinds of stories which survive within families. The ongoing attachment to a particular cultural memory of the war, decried by some as a 'Blackadder myth', stands in opposition to the revisionist histories of the late 1990s and early 2000s. ${ }^{23}$ This gap, between some academic histories of the war, and family histories, still sometimes perceived as 'misty eyed and syrupy' has perhaps contributed to an unwillingness amongst some in the historical profession to engage with family history as a valid form of historical practice. ${ }^{24}$ Nonetheless, family history remains a key way in which people engage both with the past more widely, and in particular with the total wars of the Twentieth century as moments in which their family experiences enter onto the public stage. As Wallis argues, family history 'will play a fundamental role in promoting public engagement with the First World War over the course of the centenary. ${ }^{, 25}$ How then, is family history gendered?

While men may for many years have been the authors of formal family histories, writing autobiographies and family biographies, more informal family traditions have long been collected and passed on by women. ${ }^{26}$ Sometimes these have taken a material form: recipes, photo albums, commonplace books, christening robes, and at others they can be found in the family stories that are passed on between generations. While never solely the possession or duty of women, family traditions and histories have nonetheless often been borne by women: 
usually the primary carers of children, and thus more likely to spend time in the home, and with other family members than men, women have traditionally been the keepers and transmitters of culture. As Kate Hodgkin has shown in respect of early modern Britain, women were 'bearers of significant traditions, keepers of memory within the family for future as well as past generations. ${ }^{27}$ Given this, why has there been so little attention paid to the ways that women tell stories about the First World War? I would suggest that the gendered nature of the dominant cultural memory of the war, a memory in which men serve and suffer in the trenches of the Western Front, while women either wait, and usually grieve, at home, or nurse the injured men, has meant that less attention has been paid to the ways in which women both respond to the memories of the war that circulate on the public stage, and think about, and transmit, family histories of the war years. In the hierarchy that structures the cultural memory of the war, the male combatant, particularly the combatant in the trenches of the Western Front, is privileged over all other figures.

The figure of the sacrificial combatant has been at the heart of commemoration and memorialisation of the war years since its immediate aftermath. While cultural memory is always contested, slippery and mutable, the presence of the soldier as victim is remarkable for its stability. The cenotaph in London's Whitehall, originally erected as a temporary monument to the Empire's war dead in 1919 proved such a potent symbol of loss and bereavement that Lutyen's permanent replacement was swiftly commissioned. By 1920 the cenotaph, and the body of the Unknown Warrior, interned that year at Westminster Abbey, had come to sit at the heart of British commemorative practice which was itself echoed in similar rituals and memorials around the Empire. Although the importance of this figure faded in the 1940s and 1950s, and was being contested in Britain by the late 1930s, the early 
1960s saw its definitive re-emergence. ${ }^{28}$ Driven by the confluence of the $50^{\text {th }}$ anniversary of the war and by the anti-establishment and anti-war movements of the decade, the 1960s saw the rediscovery of the war poets and the growing visibility of Wilfred Owen as the key figure of the war; a soldier poet who mourned the death of young men in industrial warfare and who was to become a sacrificial figure himself, dying just before the Armistice. ${ }^{29}$ It is this cultural memory of the war, with its focus on tragedy, doomed youth, mud, the missing and the trenches that has, despite the best efforts of Michael Gove and revisionist historians, continued to resonate in British culture. ${ }^{30}$

It is against this shifting and multi faceted cultural memory of the war that the respondents to the MO Project Directive of 2014 were writing. With relatively few representations of the multiple female experiences of war circulating on the public stage, it is perhaps not surprising that many of the older women writing for MO, several of whom had first hand, lived, experience of 'total' war, often focused on the legacies of the male veteran in both their recounting of family histories and in their sense of the ways that the war should be remembered. The next section examines the extent to which this gendered cultural memory interacted with family history and the practice of writing for MO to shape the ways that women of 'the generation after' wrote about the war in their Directive replies.

\section{Gender, Life Writing and Mass Observation}

Dorothy Sheridan, who was for many years the archivist at MO, has described writing for the project as a form of life writing, or a 'collective autobiography' which gives us access to some aspects of everyday life in modern Britain. Sheridan writes that, through people's 
responses to MO Directives, 'we may come to learn about people's hopes and fears, their individual choices in relation to wider social and political change, their rational and unconscious motives for acting, and above all, the meaning and significance which they give to their lives. ${ }^{31}$ If we understand the practice of writing for MO as a form of life writing then, we need to think about the ways in which it differs from, and has similarities to, other forms of life writing and life telling, such as the oral history interview, the memoir, the formal autobiography and the online blog. As with these other forms of life writing and life telling, Mass Observers choose to produce a sense of self in a public form; unlike memoirs, autobiographies and online blogs however, they respond to specific questions and agendas set by the Directive authors. Like the oral history interview, MO volunteers are responding to a set of, usually, open ended questions; unlike the interviewee however, they write their responses, and can more easily decide whether or not to respond to a particular Directive or to particular questions. They are thus arguably more likely to successfully achieve and maintain a sense of composure in their writings; to craft answers which can act to validate their sense of self and which support a particular point of view or a life narrative. Difficult questions, or Directives, can simply be ignored as there is no imperative to answer each one. ${ }^{32}$

There is also an inter-subjective dimension to MO writing. While, unlike the subjects of oral history interviewers, the panellists are not engaged in a personal conversation with an investigator, many convey a sense of the audience they believe they are writing for, and whom they are addressing. ${ }^{33}$ For example, a retired clergyman began his response by explaining that he would not 'jot down ten words/phrases that conjure up World War One' (the first exercise the respondents were asked to undertake), because 'it seems rather a 
pointless exercise, and I hope the person sponsoring this exercise takes that comment to heart. ${ }^{34}$ Mass Observers are also motivated by the sense of taking part in a collective project, in contributing to the enhancement of social knowledge. ${ }^{35}$ They often present themselves as critics of wider social beliefs and vested interests, giving voice to views that are less often heard, an alternative to 'an increasingly powerful media and state which are perceived as manipulative and failing to represent public opinion fairly. ${ }^{, 36}$ This sense of providing a critical voice may have led to the wide-ranging criticism of, and scepticism towards, much of the centennial commemorative practice articulated by many of the respondents. ${ }^{37}$ The fact that more women than men write for MO today, and that the current panel is weighted towards older authors may well reflect a sense amongst older women that they and their views and values are largely invisible and often under-valued on the wider stage of public debate and commentary in contemporary Britain.

While the MO panel are not a representative sample of the population, the strength of the material they produce for historians lies in the access that it gives us to the constant processes of subjectivity formation. ${ }^{38}$ In common with the other, multiple 'technologies of the self' upon which the modern individual can draw, writing for MO can be understood as one way in which subjectivity is both composed and performed. The process of writing for the project can thus be understood as one way of 'writing the self', and in this production of selfhood, of subjectivity, the authors draw upon public accounts of the past, of events and of identities. In this 'cultural circuit' private and public accounts of the past become intermingled and shape one another: public versions of past events reflect more intimately produced stories which enter public discourse; public versions of events shape the more private renderings of one's 
own life and opinions. Individuals make use of public stories and cultural memories that help them to produce a composed and coherent sense of self.

In this circuit, some versions of the past, and some subjectivities, become more 'speakable' than others, gaining a greater purchase on the public stage, and thus a greater influence over more private accounts. For example, the currently dominant cultural memory of the First World War makes stories of relatives and ancestors who were harmed or traumatised by the war perhaps more visible than stories of those who had a 'good' war, and who benefitted from the shifts and changes that total war bought in its wake. ${ }^{39}$ While many of the respondents, across both gender and generation, stated that they participated in the rituals of Remembrance Sunday, and felt them to be important, many others expressed a sense that not only was the First World War a needless loss of life, but that the centenary commemorations were an attempt to manipulate public opinion, to celebrate, rather than to commemorate, Britain's history as a military nation, and by so doing, to ensure support for current and future conflicts. This belief, often expressed as a hostility to the practices of Remembrance Day, is less often articulated in wider public forums, and the opportunity to write for MO may well have given many of the respondents an occasion on which to 'vent' feelings of frustration, anger and cynicism that are difficult to express elsewhere. One woman in her thirties argued that Remembrance Day was 'too militaristic - it seems to glorify war and the soldiers who died' while a woman in her sixties complained that 'the orthodoxy is to be totally involved in remembering total war ${ }^{40}$ For contributors such as these, writing for this Directive may have both given them an opportunity to express views often silenced elsewhere, and to produce and perform a sense of themselves as critical and reflective citizens. 


\section{Women Writing on War}

So how did the women examined in this article, born between the 1920s and the early 1950s, write about the First World War in 2014? To what extent were their personal reflections and family histories reflective of the stories and representations of the First World War that circulate today, or that were circulating in earlier periods of these women's lives? The first, and most striking aspect of almost all of the writing by these women in response to the Directive is the extent to which they chose to write about the male experience of war, and particularly about the soldier on the Western Front, the figure who lies as the heart of the cultural memory of the war in Britain. Indeed, only one woman put her mother's history, rather than that of a male relative, at the heart of her narrative. ${ }^{41}$ The prevalence of the soldier-victim in the writings of respondents whose age meant that they did have memories of the direct impact of the war on their families however, suggests that the cultural power of this figure has acted to shape these memories, or the way they are articulated, perhaps making it more difficult for positive wartime experiences to be expressed. The experiences of these soldiers that the respondents focused on largely sat comfortably within the dominant cultural memory of the Western Front as a place of mud, blood, futility and sacrifice. The first exercise that respondents were asked to complete, and which so angered the man quoted above, was a list of ten words or phrases that they associated with the First World War. The list of words that respondents associated with the war were comparable across genders and ages: a 78 year old widow's list of 'bloodied, muddied, battlefields, inhumanity, appalling loss of life, lack of diplomacy, cenotaph, unforgotten, lambs to the slaughter, youth, pals, (and) bereaved' was fairly typical, similar for example to the 'death, blood, mud, futility, young men, uniforms, nurse, bandages, gas, (and) trenches' listed by a 55 year old housewife 
and the listing of 'mass slaughter, mud, trenches, horses, the cenotaph, Oh! What a Lovely War, Blackadder Goes Forth, war poets' by a 70 year old man. ${ }^{42}$ These are strikingly similar to the lists produced annually by students at the University of Brighton at the beginning of an optional course on Europe in the First World War, and by students at the University of Exeter taking a similar course. ${ }^{43}$ If we understand these lists as an indicator of the cultural memory of the war that the respondents were operating within, it is perhaps not surprising that the stories that were recounted emphasised soldier-victims, and their ongoing legacy within families.

Stories of death and injury were widespread: a 74 year old retired librarian recalled that her maternal grandfather had two brothers who were gassed, and that her mother-in-law's 21 year old brother had been killed, while a 68 year old widow described her grandfather dying in 1926 aged just 41 as a result of gas inhalation. ${ }^{44}$ Others wrote of an uncle killed at Passchendale, listed as missing, and a grandmother's long cherished hope that he might return one day, and of uncles who returned, one 'severely shell shocked, the other so damaged you couldn't touch his skin. ${ }^{45}$ Some responses seem to reflect narratives of the First World War that are currently circulating within cultural memory: one woman, aged 84 recounted a friend's memories of the 1914 Christmas Truce in the trenches of the Western Front, commenting that 'this sorry tale made me realise the futility of war'. ${ }^{46}$ Another respondent perhaps drew on the popularity of the Michael Morpugo novel War Horse, now both a successful film and theatre production when relating how her grandfather 'spoke of his pain when most of the farm horses were led away. ${ }^{47}$ The First World War's familial and personally felt legacies of death, injury and loss, while also recounted by several of the male 
respondents, appear to have given many of these older female respondents a means of articulating a relationship to a conflict largely represented as a male experience.

Despite this focus on the traumatic legacies of the Western Front for their families, several women prefaced their comments about trench warfare with a gendered disclaimer: one respondent began a lengthy and informed reply with the comment 'I won't be able to remember and place in time the names of various battles, so there's no clue there'.

Knowledge of military history, strategy and tactics was largely understood as a male preserve, one woman explaining that 'my husband was always interested in the war and he had lots of books about it' while another remarked that 'my husband is interested in war generally...he also had a bit of a thing about the Battle of Jutland, and I know that's World War One! ${ }^{48}$ While many of the older women discussed in this article actually had a great deal of knowledge about the war, often being widely read and several having visited the battlefields of the Western Front, none claimed a knowledge of military or political history in their reflections on the war years, instead relying upon their knowledge of the war's multiple familial and personal legacies for an authoritative voice.

This gendered division of knowledge was echoed in many of the male responses. Men listed their non-fiction reading on the First World War and drew on their knowledge of the war to criticise dramatic representations for inaccuracy, one man complaining that all sorts of basic mistakes crop up and on every occasion there is a character who was too young to have joined up without the connivance of a recruiting officer, or a youngster who could not take the strain and was shot at dawn because of it. So very, very predictable. ${ }^{49}$ 
Younger men sometimes supplemented this with a description of their childhood interest in war games and games of strategy, again using their expertise in what appears to be a gendered activity to articulate their views on the war from a particularly authoritative position, a middle-aged IT consultant explaining that 'the reality was that this was a war fought between empires...it was based on a paradigm of international relations that became outdated. ${ }^{50}$ Another man, after listing the factual books he had read on the war made a plea for more coverage of 'the economic, logistical, medical or technological aspects' and less on the 'blinkered and sentimentalised view'. ${ }^{51}$ In this, the responses echoed those of MO authors in the 1980s and 1990s: when asked to write about the Falklands and Gulf Wars, men were able to draw upon a gendered knowledge and military experience in order to speak with a level of authority that was rarely available to the female respondents, even those with lived experience of warfare. ${ }^{52}$ It's striking that in the case of the First World War, which none of the respondents had directly experienced, knowledge of military history, tactics and strategy gave some of the men who replied a sense of expertise and a concurrent belief that their views bore more weight than those without such knowledge. These men were able to convey a sense of composure and authority in their responses that was often absent from the replies of those who drew primarily on family histories and popular culture when framing their thoughts about the First World War.

For several of the respondents the First and Second World Wars were interwoven in their sense of the past, and in their own life histories. While some younger respondents began their replies by expressing their confusion between the First and Second World Wars when there were no living relatives who had experienced either conflict, for others the wars were linked by an emotionally charged sense of their impact and legacies. ${ }^{53}$ Empathy for the dead and the 
bereaved of the First World War was articulated through their own experiences of loss in wartime. Questions about the First World War prompted some respondents to reflect on their memories of bereavement in the Second. One woman, who had served in the Women's Auxiliary Air Force during the Second World War, and who attributed her father's disdain for non-combatants in that conflict to his own wartime experience between 1914-18, recalled the death of her husband's navigator, and 'the shock of his father's visit many years later, when we discussed this boy's death in the war... and the subsequent death of his mother, who died of a 'broken heart', 54 The woman, born in 1923, who described her grandfather's sadness when the horses were taken from the farm where he worked during the First World War moved in the same sentence to her own visit to the Second World War Commonwealth War Graves Cemetery at Monte Cassino, where she 'walked around, with tears running down, reading the names and ages of the young men. ${ }^{55}$ While these women clearly separated the history of the two wars, the emotional experience and legacy of conflict, understood as one of grief, loss and bereavement for theirs and their parent's generations, was common to both, and, drawing on their personal and generational experiences, questions about the First World War led to reflections on the losses of the Second. ${ }^{56}$

These responses were shaped by what the historian Joy Damousi, writing about the impact of the First World War in Australia, has termed 'the labour of loss'. This, Damousi argues, is both emotional labour, as the bereaved struggle to overcome the shock of untimely death, but also social and cultural labour, as they are expected to perform roles specific to death in war - that of the proud parents, or the brave widow. ${ }^{57}$ The reflections on loss articulated here by several of the women demonstrate both the lasting emotional legacies of wartime death, but 
also the particular role of women as mourners. A 94 year old woman remembered the shrine a neighbour kept in her house to a dead son while another said she looked 'in absolute horror at any celebrations as I think of all the millions of young men who were killed' ${ }^{58}$ A 78 year old widow described the silence on Remembrance Day as 'overwhelming when you consider the grief of the bereaved', and for a woman in her 80 s the grief of the bereaved, read through the traditions of Remembrance Sunday, was never ending, as 'not even time makes the mourning any the less. ${ }^{59}$ A sympathetic discussion of the dead and injured combatants was common to many of the respondents, but older women in particular expressed a compassion for not just the young soldiers, but for their wives and mothers, producing though their writing a subjectivity that was both empathetic and gendered, shaped by an identification with the perceived emotions of the bereaved women.

Female bereavement, as we have seen, was personified both by mothers who had lost sons, and by women who had lost lovers, fiancées and husbands. The idea of a 'lost generation', expressed so powerfully by Vera Brittain, was a gendered narrative, in which men died, and women were left behind, unable to find a romantic partner from amongst the denuded male population. Reflections on this loss were common: one woman described how 'I often think of the women who never married... and the men who never returned', another recalled an elderly friend of her childhood who had never married after her fiancée was killed in the war, while another remembered 'having lots of aunties as a child as... there was a shortage of marriageable age men. ${ }^{60}$ The only respondent to put a woman at the heart of her family history of the war wrote her mother's history as a combination of romance, early loss, and feminine strength, endurance and bravery. In this response, the First World War forms a backdrop to a home front focused account of courtship, work patterns, childbirth and death, 
as her mother's first husband, weakened by his war injures, died in 1918 from the Spanish Flu, aged just $21{ }^{61}$ This narrative combines romance with a feminist claim to female independence and power; a perspective that runs through many histories of woman and war, but which is absent from the other responses, perhaps a victim of the soldier-victim motif that has become so dominant.

Many of the responses to the Directive by older women express a sense of the necessity of handing down their knowledge of the war and its impact to the younger members of their family. While this was articulated by one man, who termed himself 'the family historian' many of the older women writers had a less formal sense of themselves as bearers of a family history, but instead often wrote about what they perceived as a gulf of knowledge and interest between themselves and their children or grandchildren. ${ }^{62}$ In this, they have much in common with the female family historians of $17^{\text {th }}$ century England described by Katharine Hodgkin as 'keepers of family memory, transmitting the past through the present for the use of the future. ${ }^{93}$ Like their forebears, several of the women writing in 2014 expressed a sense that it was their duty to ensure that future generations understood both what the war had meant to their family, but also that they passed on a particular, contemporary cultural memory of the war as a time of tragedy, loss and sacrifice. At times, the articulation and use of this sense of the past was dynamically shaped by the exact circumstances of the present: a 60 year-old retired teacher, who felt her family were unjustly criticising her for feeling sorry for herself when she had a cold, responded by reminding her children 'of those that died at their age on the battlefields 100 years ago, and how lucky they are not to be enduring it. ${ }^{, 64}$ Another woman, aged 74, explained exactly why she had started to research the lives of her grandfathers who had served in the war: 'I am now the oldest member of my family and I 
realise that if I don't learn about the past and disseminate this knowledge, it will have gone forever. ${ }^{65}$ This woman expressed a sense of herself as a bridge between the lived family past and its future, transmitting what had once been lived recollection to future generations as a means of ensuring a (gendered) continuity between the family's past, present and future.

Two separate respondents had visited an exhibition on the First World War at Brighton Museum, which used artefacts and family histories to tell the individual wartime stories of a range of people from the city, intercut with reflections from contemporary observers. ${ }^{66}$ The exhibition, which was extremely popular, was notable in part for its expectation of an emotional response from visitors; Pachelbel's Canon in G Minor played quietly throughout the galleries, and placed discreetly next to the book for visitor comments at the gallery's exit was a box of paper tissues. The emphasis of the exhibition was on the individual in wartime, and while a range of different experiences were covered, the expectation amongst both curators and most visitors appears to have been that of an empathetic response to the plight of those who were caught up in the cataclysm of war. This was certainly the response of the two respondents. However, they had been accompanied in one case by grown-up children and in another by grandchildren, and while they had found the exhibition moving, their children and grandchildren had been 'underwhelmed', a response that both women understood as shaped by the impact of new media on their attention spans. ${ }^{67}$ A sense of 'bearing witness', albeit to events that they had not personally experienced, was important to both of these respondents, one woman writing 'we have to bear witness to the dreadful things that happened in the past, even if it was a totally different age, and tell our children what happened' ${ }^{68}$ It's notable that the sense of the past these women wanted to pass on was not one that particularly engaged with the macro history of the war, with its geo-politics, its 
causes or the historiographical debates that have raged around this. Instead, they wanted to pass on a sense of the war that drew on emotional responses for its politics, employing an empathy with both the soldier-victim and his loved ones to ensure future generations understood the full cost of war, and would draw on this to place themselves in opposition to more current and contemporary conflicts. 'Lest we forget', in this context, had quite specific meanings, meanings that may not have been recognised by many of those that the centenary commemorations aim to remember.

\section{Conclusions}

The older women whose responses to this Directive on the First World War are discussed here largely produced writing which is clearly recognisable as contemporary, as shaped not only by family histories and by the women's life course, but also by the cultural memory of the First World War that has dominated since the 1960s, a shared sense of the past which has at its heart the figure of the soldier-victim. This figure appeared in the majority of the narratives examined here, either as a relative who failed to return from the war, or who did return but injured and damaged, or as a more abstract figure, one of the numerous military victims of warfare to whom the nation gathers to pay tribute every Remembrance Sunday. Compassion and empathy, both for these men and for the women at home, shaped the writings of these women. While these responses were also expressed by younger women and by men, these other groups also wrote about the war in other ways, perhaps focusing on the military or political history of the war, or using the Directive to reflect on what some saw as a manipulation of the past by the current government, keen to ensure support for contemporary conflicts by a continued reverence for the service and sacrifice of combatants of past wars.

Older women, while also sometimes expressing a scepticism about remembrance practices, or 
alternatively articulating why they saw participation in such practices as important, all wrote sympathetically about the plight of both the soldiers and of those who loved them.

While they do not constitute one generation, being born across a period of almost thirty years, there is a commonality in the responses to the First World War produced by the women considered here that bears investigation. The role of women as mourner, as the chief workers in the 'labour of loss', seems to have permeated the responses of women born in the thirty years or so after the First World War. For those who had adult experience of the Second World War, the emotional impact of the two conflicts appears as a legacy of grief, of a bereavement shared across the years. For almost all the women whose writing is examined here, the memories of returned men, or of mothers and grandmothers who had experienced loss as a result of the war, dominated over other war stories that they could, perhaps, have told. In part this was shaped by the dominant, widely shared, cultural memory of the war, and the representations of the conflict that circulate within popular culture, but it was also a gendered response, driven in large part by the perception of women as mourners and as bearers of the family story. The sacrificial mother and the grieving partner were both culturally important figures in the period between the two world wars, and in wartime since. ${ }^{69}$ The figure of the sacrificial mother, giving up her sons to the nation, remains important, a repository of not only national grief but also of national steadfastness and determination. ${ }^{70}$ Joined by the figure of the bereaved wife, fiancée or lover, the women bereaved by war were a point of identification and empathy for many of the older women writing for MO.

This empathetic position in relation to the war and its impact can be understood as part of the construction of a gendered selfhood. Feminist theorists have long argued that the process of 
composing subjectivity is gendered; that the construction of a secure feminine selfhood is complicated and made difficult by femininities' relationship to an apparently more secure masculinity, and by the multiple and contradictory discourses of femininity that circulate. ${ }^{71}$ While work on masculinity has demonstrated that masculinities are also unstable, multiple and fractured, the centrality of the soldier-victim to contemporary narratives of the First World War acted to place women in relationship to the combatant male. ${ }^{72}$ By positioning themselves as sympathetic to the historic victims of warfare, the women writing here were giving voice to a role that has long been filled by women. This position appeared to give many of the women authors a sense of composure: as a gendered means of writing about war which sat comfortably with both current cultural memory of the conflict and a historically recognised female relationship to war, and as a means of writing about family relationships and histories which may have often been difficult to negotiate, the empathetic voice seen here allowed these women to write in ways that they were comfortable with. ${ }^{73}$

These women's relationships to the generation who had experienced the war, their parents and grandparents, can be understood as a form of 'postmemory', as they inherited memories of the war and its impact which they felt important to pass on to younger generations. The centrality of the soldier-victim to the cultural memory of the war encouraged responses which focused on the experience and legacy of dead, injured and traumatised men for their families. In articulating an empathetic relationship to both these men and to those who loved them, the women produced responses to the Directive that were shaped by both their gender, and by the function of family history as a means of bringing together past, present and future generations. Rather than simply transmitting stories of the past, these Directive responses should be understood as dynamic, shaped as much by the subjectivity of the narrator and their 
relationship to family and to current cultural memories of the war as by the experiences and legacies being recounted. Age, gender and family position thus interacted in these responses to produce a body of writing which was shaped by a desire to pass on an empathetic understanding of the First World War, and its negative impact for those who lived through it, to future generations.

The author wishes to thank the Trustees of the Mass Observation Archive (University of Sussex) for permission to quote from the Archive, and the AHRC First World War Engagement Centres for funding the Directive. Thanks also to Jessica Scantlebury for the figures cited in endnote 58 and to Penny Summerfield, Michael Roper and the anonymous readers of this article for their helpful and constructive comments on this research.

\footnotetext{
${ }^{1}$ For details of the work of the five Engagement Centres, see http://www.ahrc.ac.uk/research/fundedthemesandprogrammes/worldwaroneanditslegacy/worl dwaroneengagementcentres/
}

${ }^{2}$ Marianne Hirsch (2008) The Generation of Postmemory, Poetics Today, 29: 1, pp103-128, here p. 106-7.

${ }^{3}$ Hirsch, Generation of Postmemory, p.109.

${ }^{4}$ Helen McCartney (2014) The First World War Soldier and His Contemporary Image in Britain, International Affairs, 90:2, pp. 219-315, here p.219.

${ }^{5}$ Hirsch, Generation of Postmemory, p.116.

${ }^{6}$ For examples of some of these see the Heritage Lottery Funded projects that the Gateways to the First World War AHRC Public Engagement Centre has worked with. http://www.gatewaysfww.org.uk/projects. 
${ }^{7}$ See, for example, Penny Summerfield (2013) The Generation of Memory: Gender and the Popular Memory of the Second World War in Britain, in Lucy Noakes \& Juliette Pattinson (eds.) British Cultural Memory and the Second World War (London: Bloomsbury, 2013); Patrick Hayes and Jim Campbell, Bloody Sunday, Trauma, Pain and Politics, (London: Pluto Press 2005)

${ }^{8}$ Michael Roper (2009) The Secret Battle. Emotional Survival in the Great War (Manchester: Manchester University Press); Growing up in the Aftermath: Childhood and family relationships between the wars, Lecture for the British Psychological Society, 2014. Available online at: https://www.youtube.com/watch?v=FBHNyNsAuI4\&list=PLCkLQOAPOtT28X05RoZ8-31ojkigpkAl.

${ }^{9}$ Joel Morley, (2013) An Examination of the Influence of the First World War on Attitudes to Service in the Second World War Unpublished PhD, Queen Mary and Westfield, University of London.

${ }^{10}$ See for example, Gail Braybon $(1981 ; 2012)$ Women Workers in the First World War (London: Croom Helm); Joanna Bourke (1999) Dismembering the Male. Men's Bodies, Britain and the Great War (London: Reaktion Books); Susan R. Grayzel (1999) Women's Identities at War. Gender, Motherhood and Politics in Britain and France During the First World War (Chapel Hill: University of North Carolina Press); Nicoletta Gullace (2002) The Blood of Our Sons. Men, Women and the Renegotiation of British Citizenship During the Great War (Basingstoke: Palgrave Macmillan); Deborah Thom (2000) Nice Girls and Rude Girls: Women Workers in the First World War (London: I.B. Tauris); Janet K. Watson (2004) Fighting Different Wars: Experience, Memory and the First World War in Britain 
(Cambridge: Cambridge University Press); Angela Wollacott (1994) On Her Their Lives Depend: Munitions Workers in the Great War (California: University of California Press)

${ }^{11}$ See, for example, Series One of the The Village (BBC: 2013), which, while focusing entirely on life in a Peak District village during the war, has at its heart the experience of a young soldier who suffers from shell shock and is shot for desertion. In early June 2016 the 49 television and radio programmes listed by the $\mathrm{BBC}$ on its World War One page included 5 that focused on the home front and 12 that focused on the battlefront. The remainder examined the political and cultural causes and legacies of the war.

http://www.bbc.co.uk/programmes/p01nb93y/members.

${ }^{12}$ Bart Ziino (2015) Introduction: Remembering the First World War Today, in Bart Ziino Remembering the First World War (Abingdon: Routledge), pp.1-18, here p.7.

${ }^{13}$ Vera Brittan (1933) Testament of Youth (London: Victor Gollancz); Alan Bishop (ed) (1981) Chronicle of Youth. Great War Diary 1913-17 (London: Victor Gollancz); BBC Television Testament of Youth (1979); Dir. James Kent (2014) Testament of Youth.

${ }^{14}$ Penny Summerfield (1998) Reconstructing Women's Wartime Lives: Discourse and Subjectivity in Oral Histories of the Second World War (Manchester: Manchester University Press); The Generation of Memory, British Cultural Memory and the Second World War ${ }^{15}$ See Daniel Woolf (1997) A Feminine Past? Gender, genre and historical knowledge in England 1500-1800, American Historical Review, 102:3, pp. 645-679; Anne Blue Wills (2010) Mourning Becomes Her: Women, tradition and memory albums, Religion and American Culture: A Journal of Interpretation, 203, pp.93-121.

${ }^{16}$ Pierre Nora, (1989), Between Memory and History: Les Lieux De Mémoire, Representations, pp.7-25. 
${ }^{17}$ Paul Basu (2005) MacPherson Country: Genealogical Identities, Spatial Histories and the Scottish Diasporic Landscape, Cultural Geographies, 12:2, pp.123-150; Anne-Marie Kramer (2011) Mediatizing Memory. History, Affect and Identity in Who Do You Think You Are?, European Journal of Cultural Studies, 14:4, pp. 428-445; Ronald Lambert (1996) The Family Historian and Temporal Orientations Towards the Ancestral Past, Time and Society, 5:2, pp. 115-143; Carol Smart (2007) Personal Life: New Directions in Sociological Thinking (Cambridge: Polity Press).

${ }^{18}$ Anne-Marie Kramer (2011) Kinship, Affinity and Connectedness: Exploring the role of genealogy in personal lives, Sociology 45:3, pp.379-395, here p.380.

${ }^{19}$ On this see Anne-Marie Kramer (2011) Mediatizing Memory, European Journal of Cultural Studies, 14:4. Pp.428-445. For a recent example of academic history which explicitly engages with family history research and related methodological issues, see Alison Light (2015) Common People: The history of an English family (London: Penguin). ${ }^{20}$ https://livesofthefirstworldwar.org/; http://www.bbc.co.uk/history/ww2peopleswar/ ${ }^{21}$ See Ziino's insightful analysis of this phenomenon. Bart Ziino (2010) 'A Lasting Gift to His Descendants': Family memory and the Great War in Australia, History and Memory, 22:2, pp.125-146.

${ }^{22}$ James Wallis (2015) Great-Grandfather, What Did You Do in the Great War? The phenomenon of conducting First World War family history research, in Ziino, Remembering the First World War, pp.21-38, here p.21.

${ }^{23}$ See Michael Gove 'Why does the Left insist on belittling true British heroes?', The Daily Mail, 2 January 2014. On recent histories of the war, including revisionist histories of both battle front and home front, see Heather Jones (2013) As the Centenary Approaches. The regeneration of First World War historiography, The Historical Journal, 56:3, pp. 857-878. 
${ }^{24}$ Tanya Evans (2011) Secrets and Lies. The radical potential of family history', History

Workshop Journal 71:1, pp.49-73 here p.29.

${ }^{25}$ Wallis, Great-Grandfather, What Did You Do in the Great War? p. 24.

${ }^{26}$ For studies that discuss and utilise male autobiography see, for example, Patrick Joyce

(1994) Democratic Subjects: the Self and the Social in Nineteenth Century England

(Cambridge: Cambridge University Press); David Vincent (1981) Bread, Knowledge and

Freedom: A study of nineteenth century working class autobiography, (London: Metheun);

Julie-Marie Strange (2015) Fatherhood and the British Working Class, 1865-1914,

(Cambridge: Cambridge University Press).

${ }^{27}$ Katharine Hodgkin, (2013) 'Women, Memory and Family History in Seventeenth Century

England' in Erika Kuijpers, Judith Pollmann, Johannes Muller and Jasper Van Der Stehen (eds.) Memory Before Modernity: Practices of Memory in Early Modern Europe (Leiden: Brill), pp. 297-313, here p.312.

${ }^{28}$ On Armistice Day between 1919 and 1945 see Adrian Gregory, The Silence of Memory; on Mass Observation and Armistice Day between 1937 and 1941 see Lucy Noakes (2015) A Broken Silence? Mass Observation, Armistice Day and everyday life in Britain, 1937-1941, Journal of European Studies, 45:4, pp.331-346.

${ }^{29}$ For a tracing of the cultural memory of the First World War between the war itself and the early $21^{\text {st }}$ century, see Todman, The Great War. (2005).

${ }^{30}$ Michael Gove Daily Telegraph, 3 January 2014.

${ }^{31}$ Dorothy Sheridan (1993) 'Writing to the Archive. Mass-Observation as Autobiography', Sociology (27:1) pp. 21-40, here p. 28. 
${ }^{32}$ On the issue of composure in oral history interviews, see Penny Summerfield (2004)

'Culture and Composure: Creating Narratives of the Gendered Self in Oral History Interviews', Cultural and Social History, 1:1,pp. 65-93.

${ }^{33}$ On the ways that respondents write 'to' the archivists, see Sheridan, 1993 'Writing to the Archive'.

${ }^{34}$ Mass-Observation Project Directive (henceforth MO), Autumn 2014, Respondent no. B2710.

${ }^{35}$ Summerfield, 'The Generation of Memory'.

${ }^{36}$ Tony Kushner (2004) We Europeans? Mass-Observation, 'Race' and British Identity in the Twentieth Century (Aldershot: Ashgate), p. 256.

${ }^{37}$ See, for example MO, Autumn 2014, Respondent no's A1706, A4127, B42, B1 180 and B3227.

${ }^{38}$ Of the 198 who responded to this Directive, 199 were women, and 162 lived in England. There are no figures for social class or ethnicity, but of the 162 respondents from England, 143 lived in areas designated as areas with low levels of deprivation (see English Indices of Deprivation, 2010. https://www.gov.uk/government/statistics/english-indices-of-deprivation2010). 79 of the respondents to this Directive, both male and female, were born before 1951 . ${ }^{39}$ Dan Todman (2008) 'The Ninetieth Anniversary of the Battle of the Somme' in Michael Keren \& Holder Herwig (eds) War Memory and Popular Culture: Essays on Modes of Remembrance and Commemoration (North Carolina: McFarland).

${ }^{40}$ MO, Autumn 2014, Respondent No C3210.

${ }^{41}$ MO, Autumn 2014, Respondent no F1373.

${ }^{42}$ MO, Autumn 2014, Respondent no’s B1771, C3315. 
${ }^{43}$ Catriona Pennell (2012) Popular History and Myth-Making: The role and responsibility of First World War historians in the centenary commemorations, 2014-18, Historically Speaking, 13:5, pp.11-14, here p.11.

${ }^{44}$ MO, Autumn 2014, Respondent no’s H2639, L002

${ }^{45}$ MO, Autumn 2014, Respondent no's H2637, B1180.

${ }^{46}$ MO, Autumn 2014, Respondent no H260.

${ }^{47}$ Michael Morpurgo (1982) War Horse (London: Kaye and Ward Ltd); MO, Autumn 2014, Respondent no H266.

${ }^{48}$ MO, Autumn 2014, Respondent no's A1706, J1890.

${ }^{49}$ MO, Autumn 2014, Respondent no's B2710, B4318.

${ }^{50}$ MO, Autumn 2014, Respondent F4873, G1846.

${ }^{51}$ MO, Autumn 2014, Respondent G4374.

${ }^{52}$ Lucy Noakes (1998) War and the British: Gender, memory and national identity 19391991 (London: I.B. Tauris).

${ }^{53}$ MO, Autumn 2014, Respondent no B4458.

${ }^{54}$ MO, Autumn Directive, Respondent no F1560.

${ }^{55}$ MO, Autumn Directive, Respondent no H266.

${ }^{56}$ On death, loss and grief in Second World War Britain, see the special edition of Journal of War and Culture Studies 'Silenced Mourning' 8:1; Pat Jalland (2012) Death in War and Peace: A history of loss and grief in England, 1914-1970 (Oxford: Oxford University Press). ${ }^{57}$ Joy Damousi (1999) The Labour of Loss. Mourning, memory and wartime bereavement in Australia (Cambridge: Cambridge University Press).

${ }^{58}$ MO, Autumn Directive, Respondent No’s E174, F1560.

${ }^{59}$ MO, Autumn Directive, Respondent No's B1771, F 310. 
${ }^{60}$ MO, Autumn 2014 Directive, Respondent No's B1771, H1705, L1991.

${ }^{61}$ MO, Autumn 2014 Directive, Respondent No F1373.

${ }^{62}$ MO Autumn 2014, Respondent No A4127

${ }^{63}$ Hodgkin, 'Women, Memory and Family History', p.302.

${ }^{64}$ MO, Autumn 2014, Respondent No G1846.

${ }^{65}$ MO, Autumn 2014, Respondent No F3641.

66 'War Stories: Voices From the First World War', Brighton Museum and Art Gallery, 12 July 2014-1 March 2015. See http://brightonmuseums.org.uk/brighton/about/brightonmuseum-past-exhibitions/past-exhibitions-2014/war-stories/

${ }^{67}$ MO, Autumn 2014, Respondent No’s L1991, L4071

${ }^{68}$ MO, Autumn 2014, Respondent No L4071.

${ }^{69}$ For a recent and highly pertinent example of this, see the Armed Forces Memorial at the National Memorial Arboretum, Staffordshire. Dedicated in 2007 and designed to commemorate British Service personnel killed on active service since 1945 it contains a bronze sculpture of a dead soldier, carried on a bier by his comrades and watched by a grieving woman and distraught child.

${ }^{70}$ Susan R. Grayzel (1999) Women's Identities at War: Gender, Motherhood, and Politics in Britain and France During the First World War (North Carolina: Chapel Hill Press)

${ }^{71}$ See, for example, Bronwyn Davies (1992) 'Women's Subjectivity and Feminist Stories' in Carolyn Ellis and Michael Flaherty (eds.) Investigating Subjectivity. Research on lived experience (London: Sage).

${ }^{72}$ Raewyn Connell (1995) Masculinities (Berkeley and Los Angeles: University of California Press). 
${ }^{73}$ On composure as a concept, see Graham Dawson (1994) Soldier Heroes. British Adventure, Empire and the Imagining of Masculinities (London: Routledge). 